Int. J. Dev. Biol. 59: 261-270 (2015)

doi: $10.1387 / \mathrm{ijdb} .150202 \mathrm{et}$

\title{
lon currents involved in gamete physiology
}

\author{
ALESSANDRA GALLO and ELISABETTA TOSTI* \\ Department of Biology and Evolution of Marine Organisms, Stazione Zoologica Anton Dohrn, Naples, Italy
}

\begin{abstract}
Gametes are electrogenic cells that modify their electrical properties in response to different stimuli. This behavior is due to the occurrence of ion currents flowing through ion channels located on the plasma membranes. The modulation of ion channels has been described during the processes of gamete maturation, activation and fertilization in most of the animal models studied. In particular, predominant ions involved in physiological events in oocyte and sperm have been recognized to be sodium, potassium and calcium. In this review, we give an overview on the occurrence, modulation and function of ion fluxes, from gametogenesis to early fertilization events, from marine animals to human. The implications for a dynamic role of ion currents in gamete physiology and their possible clinical and technological applications are discussed.
\end{abstract}

KEY WORDS: gamete, ion channel, ion current, oocyte, spermatozoa

\section{Introduction}

Main steps of the reproductive process are the production of the two gametes (spermatogenesis and oogenesis), their reciprocal activation and the following interaction (e.g. fertilization). Gametogenesis is underlined by meiosis, the unique process of cell division which provides the formation of haploid spermatozoa and oocytes. Gamete maturation is the last phase of gametogenesis and transforms immature cells in gametes competent for fertilization. This is the highly specialized process of cell interaction and signal transduction that generates a new individual of the same species through different events, such as recognition, binding and fusion of the two gametes. These events are also accompanied by a still unclear process that is the reciprocal activation of the gametes. First the spermatozoon is activated by the signals coming from the oocyte extracellular membranes, that induce changes either in the shape and function of the spermatozoon rendering it a motile and fusible cell and attracting it toward the oocyte. At the end of the sperm activation and just after the fusion of the two plasma membranes, the spermatozoon starts to activate the oocyte by inducing calcium ( $\mathrm{Ca}^{2+}$ ) oscillations (Gillot et al., 1990; Swann and Yu 2008) transforming its quiescence into a metabolic activated state up to cell cycle resumption (Dupont et al., 2010) that in turn triggers the program of development (Yanagimachi 1994).

Gametes are excitable cells which, during the processes of maturation and fertilization, undergo transient modifications of the electrical properties due to the activity of ion channels present on their plasma membrane. The modulation of ion channels have been widely demonstrated on the oocytes and spermatozoa of all the animals studied (Darszon et al., 2001; Hagiwara and Jaffe 1979; Tosti and Boni 2004; Tosti et al., 2013). The modifications in the plasma membrane asset have been historically first studied in marine invertebrates and then extended to mammals and human.

In this review, we will describe the presence and activity of currents flowing through the ion channels in the oocyte and spermatozoon and in the early stages which follow their interaction in the most studied animal species from marine invertebrates to human (Figs. 1,2).

\section{Why study the plasma membrane?}

The plasma membrane marks the borderline between inner and outer compartments of the cell. On the gamete plasma membrane there are located all the molecules (ligand and receptors) responsible for the events of recognition, binding and fusion. Ion channels are among these molecules and their involvement in the functionality of gametes is a matter of intense study. The plasma membrane is the site of a difference of electrical charge distribution that creates an electrical gradient named voltage. The voltage difference across the plasma membrane creates a store of potential energy that give rise to a trans-membrane potential known as resting potential.

Every excitable cell has a specific resting potential that is normally negative ranging from -10 millivolt $(\mathrm{mV})$ to $-100 \mathrm{mV}$ (DeFelice

Abbreviations used in this paper: AQP, aquaporin; AR, acrosome reaction; $\mathrm{Ca}^{2+}$, calcium; $\mathrm{Cl}^{\text {, }}$, chloride; FC, fertilization current; GV, germinal vesicle; GVBD, germinal vesicle breakdown; $\mathrm{K}^{+}$, potassium; MI, metaphase I; MII, metaphase II; $\mathrm{Na}^{+}$, sodium.

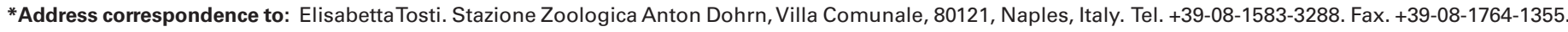
E-mail: tosti@szn.it - web: www.szn.it
}

Accepted: 22 July 2015.

ISSN: Online 1696-3547, Print 0214-6282 
1997). The voltage is due to a diverse distribution of ions inside and outside the cell. Among main important ions, potassium $\left(\mathrm{K}^{+}\right)$ is more concentrated inside the cell, whereas $\mathrm{Ca}^{2+}$ and sodium $\left(\mathrm{Na}^{+}\right)$are in the extracellular environment.

The bilayer is impenetrable to the free diffusion of the ions that may cross it only through the ion channels. These are pore-forming proteins with complex structures characterized by the properties summarized below:

i) specificity: is the passage of only one specific ion; ii) gating: is the modulation by either change of voltage or a ligand/messenger; iii) conductance: is the amount of ions that may pass thorough them; iv) sensitivity: describes what molecules/drugs are able to modulate their gating.

With the advent of the patch clamp technique in 1976 (Neher and Sakmann 1992), it has been possible to record the ion currents flowing through the cell, depending on the characteristics of the ions and the gradient across the membrane. Whole-cell and single channel recordings of channel activity are the basic configurations of the patch clamp technique. They are obtained after a seal of the plasma membrane with the glass electrode connected to the electrophysiological apparatus, but only the whole-cell configuration requires the destruction of the patched membrane to obtain free access to the cytoplasm. The single channel configuration allows a recording of the channel activity inside the intact patched membrane. The study of ion currents has provided basic information about cell physiology and function.

\section{Ion currents in gametes}

\section{The oocyte}

Oocytes are quiescent cells arrested at different stages of the meiotic cycle depending on the species. Earlier studies on the role of ions in the oocyte were performed on the sea urchin by Edward Chambers (Chambers 1989) who investigated the ionic exchange of $\mathrm{Na}^{+}$and $\mathrm{K}^{+}$at fertilization. Among echinoderms, sea urchin and starfish have been extensively studied demonstrating a wide variety of ion current activities in their oocytes.

After the pioneer studies of Chambers, mature sea urchin oocytes were investigated by several authors who better characterized the ion activity showing a high permeability to $\mathrm{K}^{+}$and a lower permeability to $\mathrm{Na}^{+}$(Jaffe and Robinson 1978; Steinhardt et al., 1971). Following studies (Dale and de Santis 1981) demonstrated a decrease of $\mathrm{K}^{+}$permeability along oocyte maturation accompanied by a decrease in the membrane conductance. The presence of $\mathrm{Ca}^{2+}$ current activities was instead firstly demonstrated in a comparative study (Okamoto et al., 1977).

Immature oocytes of different starfish species were studied in the early ' 80 especially pointing on the modification of the electrical asset associated to the 1-methyladenine induced maturation (Moreau et al., 1985).

Oocytes of Leptasterias hexactis exhibited three types of voltage-dependent currents, i.e. an inward $\mathrm{Ca}^{2+}$, a fast transient $\mathrm{K}^{+}$and an inwardly rectifying $\mathrm{K}^{+}$ current, that gradually changed during in vitro maturation, in particular the $\mathrm{Ca}^{2+}$ current become larger whereas both $\mathrm{K}^{+}$currents become smaller (Moody and Bosma 1985; Moody and Lansman 1983). The changes in the ion current kinetic were particularly evident at the end of the growth phase and were associated with the migration of the germinal vesicle (GV) at the periphery of the cell (Moody 1985).

Fig. 1. Ion channel/current activities in gametes of invertebrates. Types of ion currents/channels involved in the physiology of different maturation stages of invertebrate gametes. Oocytes are reported as GV immature stage and MI mature stage in ascidians, starfish and mollusks and MII mature stage in sea urchin. Spermatozoa are reported as immature spermatids and mature spermatozoa stages. In oocyte ion currents/channels are involved in either growth, maturation and fertilization. In spermatozoon ion currents/ channels are involved in either maturation, activation, motility, chemotaxis and acrosome reaction. 
The modifications during oocyte maturation in starfish species were associated to a decrease in membrane conductance, a depolarization of the membrane potential attributed to a change in $\mathrm{Na}^{+}$and $\mathrm{K}^{+}$conductance (Dale et al., 1978; Miyazaki et al., 1975a; Miyazaki et al., 1975b; Moreau and Cheval 1976) and an hyperpolarization attributed to a reduction in chloride $\left(\mathrm{Cl}^{-}\right)$and $\mathrm{Na}^{+}$ permeability (Shen and Steinhardt 1976).

Following studies also confirmed that modifications of three major voltage-dependent currents underlined the maturation process in other two starfish species (Henrician leviuscula and Asterina miniata) (Simoncini and Moody 1990).

Ascidians are marine invertebrates whose oocytes are very suitable for the electrophysiological studies due to their extracellular coat that is very easy to removed, facilitating the access to the nude plasma membrane. Thanks to these characteristics, ascidian oocytes have been widely investigated. That ion currents in mature oocytes play a role in regulating early developmental processes in ascidians was early suggested by several authors at the end of 80'. In fact in Boltenia villosa metaphase I (MI) oocytes, three major voltage-dependent currents were described: a transient, inward $\mathrm{Na}^{+}$current; a transient, inward $\mathrm{Ca}^{2+}$ current and an inwardly rectifying $\mathrm{K}^{+}$current differently relating each one of these currents with following developmental events (Block and Moody 1987).

By using the whole-cell voltage clamp technique we characterized the electrical properties of immature oocytes of two ascidian species (Silvestre et al., 2009; Tosti et al., 2013). Although accurate electrophysiological characterizations in Ciona intestinalis first described the presence of L-type $\mathrm{Ca}^{2+}$ currents in the mature Ml oocytes (Bosma and Moody 1990; Dale et al., 1991), we showed a decline in the amplitude of these currents during the passage from GV to MI stage. In Ciona intestinalis oocyte plasma membrane, it was shown a higher L-type $\mathrm{Ca}^{2+}$ current activity at the GV stage in comparison to the following mature stage when $\mathrm{Na}^{+}$currents start to appear (Cuomo et al., 2006). The need for $\mathrm{Ca}^{2+}$ in the immature oocytes was also supported by the fact that these oocytes undergo a spontaneous maturation in presence of $\mathrm{Ca}^{2+}$. Later on, we better characterized the immature oocytes identifying three classes with different electrical features and demonstrated the gradual disappearance of high L-type $\mathrm{Ca}^{2+}$ current activity in favor of appearance of $\mathrm{Na}^{+}$currents that remained high throughout maturation up to the post-vitellogenic stage (Silvestre et al., 2009). Of particular interest is the role of $\mathrm{Na}^{+}$currents in the mature oocyte. In fact, we showed that by depriving of $\mathrm{Na}^{+}$or by inhibiting the channels with tetrodotoxin the in vitro fertilization give rise to an anomalous 8-cell embryo

Fig. 2. Ion channel/current activities in gametes of vertebrates. Types of ion currents/channels involved in the physiology of different maturation stages of vertebrate gametes. Oocytes are reported as GV immature stage and MII mature stage. Spermatozoa are reported as immature spermatids and mature spermatozoa stages. In oocyte ion currents/channels are involved in either growth, maturation and fertilization. In spermatozoon ion currents/channels are involved in either maturation, activation, motility, chemotaxis and acrosome reaction. called rosette; furthermore the fertilization current in an environment $\mathrm{Na}^{+}$free undergoes a reduction in the amplitude (Cuomo et al., 2006). This clearly show that $\mathrm{Na}^{+}$currents play a relevant role in the generation of first electrical events of fertilization and this is also in agreement with previous experiments (Tosti et al., 2003) in which the inhibition of FC resulted in a long term effect on the normal embryo development. Nonetheless there is a general consensus for a role of L-type $\mathrm{Ca}^{2+}$ currents during oogenesis and maturation, surprisingly we recently showed, in the oocytes of the ascidian Styela plicata, an activity of T-type $\mathrm{Ca}^{2+}$ currents that underlie the nuclear maturation progress and oocyte growth by also inducing a progressive hyperpolarization of the membrane

\begin{tabular}{|c|c|c|c|}
\hline Vertebrates & Gamete & Currents/Channels & Refs. \\
\hline Amphibians & & $\begin{array}{c}\mathrm{H}^{+}, \mathrm{K}^{+}, \mathrm{Na}^{+}, \mathrm{Cl}, \\
\text { L-type } \mathrm{Ca}^{2+}, \\
\mathrm{Ca}^{2+} \text { dependent } \mathrm{Cl}^{-}, \\
\text {mechanosensitive cation }\end{array}$ & $\begin{array}{l}\text { Barish, } 1983 \\
\text { Barish \& Baud, } 1984 \\
\text { Baud, 1983 } \\
\text { Ivorra \& Morales, } 1997 \\
\text { Jaffe \& Cross, } 1984 \\
\text { Lane et al., } 1991 \\
\text { Morrill \& Ziegler, } 1980 \\
\text { Ouadid-Ahidouch, } 1998 \\
\text { Schlichter, 1989, } 1983 \\
\text { Wilkinson et al., } 1998\end{array}$ \\
\hline Fishes & & $\mathrm{Ca}^{2+}$ & $\begin{array}{l}\text { Cook et al., } 1994 \\
\text { Ho \& Suarez, } 2001 \\
\text { Suarez and Ho, } 2003\end{array}$ \\
\hline Rat & & $\begin{array}{l}\mathrm{K}^{+}, \mathrm{Na}^{+} \\
\mathrm{Ca}^{2+}, \mathrm{Cl}^{-}\end{array}$ & $\begin{array}{l}\text { Chan et al., } 1997 \\
\text { Hagiwara \& Kawa, } 1984\end{array}$ \\
\hline \multirow[t]{2}{*}{ Mouse } & & $\begin{array}{c}\mathrm{Ca}^{2+}, \mathrm{L} \text {-type } \mathrm{Ca}^{2+} \\
\text { Aquaporins }\end{array}$ & $\begin{array}{l}\text { Murnane et al., } 1988 \\
\text { Murnane \& DeFelice, } 1993 \\
\text { Yamaji et al., } 2011\end{array}$ \\
\hline & & $\begin{array}{c}\mathrm{K}^{+}, \mathrm{Na}^{+}, \mathrm{Ca}^{2+}, \mathrm{Cl}^{-} \\
\text {L-type } \mathrm{Ca}^{2+}, \mathrm{T} \text {-type } \mathrm{Ca}^{2+\mathrm{Ca} 2+} \\
\text { CatSper, } \mathrm{K}^{+}(\mathrm{SLO} 3)\end{array}$ & $\begin{array}{l}\text { Arnoult et al., } 1996 \\
\text { Benoff, } 2008 \\
\text { Darszon et al., } 2011 \\
\text { Darszon, } 2001 \\
\text { Escoffier et al., } 2007 \\
\text { Florman et al., } 1998 \\
\text { O'Toole et al., } 2000 \\
\text { Patrat et al., } 2000 \\
\text { Qi et al., 2007 } \\
\text { Ren et al., } 2001 \\
\text { Reyes et al., } 1994 \\
\text { Santi et al., } 1998 \\
\text { Son et al., } 2002\end{array}$ \\
\hline Bovine & & $\begin{array}{c}\mathrm{Ca}^{2+} \\
\mathrm{L} \text {-type } \mathrm{Ca}^{2+}\end{array}$ & $\begin{array}{l}\text { Nichols, } 2006 \\
\text { Tosti et al., } 2000\end{array}$ \\
\hline \multirow[t]{2}{*}{ Human } & & $\mathrm{K}^{+}$ & $\begin{array}{l}\text { De Felice et al., } 1988 \\
\text { Du et al., } 2010\end{array}$ \\
\hline & & $\begin{array}{c}\mathrm{K}^{+}, \mathrm{Na}^{+} \\
\mathrm{Ca}^{2+}, \mathrm{Cl}^{-} \\
\mathrm{Ca}^{2+} \text { dependent } \mathrm{K}^{+}\end{array}$ & $\begin{array}{l}\text { Bai \& Shi, } 2001 \\
\text { Chan et al., } 1997 \\
\text { Linares-Hernandez et al., } 1998 \\
\text { Patrat et al., } 2000 \\
\text { Rossato et al., } 2001\end{array}$ \\
\hline
\end{tabular}


potential. In particular, it was demonstrated a long term effect on the embryo development of these currents activity (Gallo et al., 2013). This absolute novelty further support a role of $\mathrm{Ca}^{2+}$ currents during oocyte maturation.

The role of L-type $\mathrm{Ca}^{2+}$ currents during oocyte maturation has been also supported by numerous studies on the mollusks. In Spisula, Ruditapes and Crassostrea, a $\mathrm{Ca}^{2+}$ influx through voltagegated channels is required for the occurrence of the germinal vesicle breakdown (GVBD) (Dube 1992; Leclerc et al., 2000). These findings supported the fact that an early $\mathrm{Ca}^{2+}$ influx may be a prerequisite to allow nuclear maturation in either prophase I (Colas and Dube 1998) and Ml-arrested oocytes of bivalves (Moreau et al., 1996). The involvement of L-type $\mathrm{Ca}^{2+}$ currents in these processes was also demonstrated by other authors in either Ruditapes philippinarum (Guerrier et al., 1993; Tomkowiak et al., 1997) and Octopus vulgaris (Cuomo et al., 2005) focusing on a possible role in the preparation of the plasma membrane to the interaction with the spermatozoon. In the latter, it is of interest the decrease of $\mathrm{L}$-type $\mathrm{Ca}^{2+}$ activity during the growth and vitellogenesis of oocytes. Close to a predominant role of these currents, in the mollusk Patella vulgata a change in specific $\mathrm{K}^{+}$ion permeability due to the possible activation of stretch channels was also described during oocyte maturation (Moreau et al., 1990).

Switching on vertebrates, a peculiar electrical property is that of amphibian oocytes which exhibit the unique presence of $\mathrm{Cl}^{-}$ channels in either immature and mature oocytes (Jaffe and Cross 1984; Schlichter 1989). In Xenopus laevis, other than a voltagegated $\mathrm{Na}^{+}$current described by several authors (Bourinet et al., 1992; Weber 1999) present during oocyte growth (Baud 1983), a more recent finding showed the presence of $\mathrm{Cl}^{\text {-currents and their }}$ ability to induce GVBD was demonstrated by means of molecular biology techniques (Reyes et al., 2009). Furthermore the activity of a $\mathrm{Ca}^{2+}$ dependent $\mathrm{Cl}^{-}$current in the immature oocytes was also characterized (Barish 1983). The coordination between $\mathrm{Cl}^{-}$and $\mathrm{Na}^{+}$ currents seems to modulate oocyte maturation in the frog Rana pipiens in which $\mathrm{Cl}^{-}$channels disappear throughout maturation whereas the $\mathrm{Na}^{+}$currents remain active up to the full maturity of the oocyte (Baud 1983). In same species, an hormone-induced depolarization was also associated to a decrease in $\mathrm{K}^{+}$permeability (Morrill and Ziegler 1980). Together with these patterns, the fact that $\mathrm{Cl}^{-}$currents are lost as the oocyte undergoes maturation (Schlichter 1983) suggested that $\mathrm{Cl}^{-}$and $\mathrm{Na}^{+}$channels might play a regulatory role in maturation. However, the signal coming from L-type $\mathrm{Ca}^{2+}$ channels in the regulation of the maturation process was also described in pleurodeles (Ouadid-Ahidouch 1998). In the European frog Rana esculenta, together with $\mathrm{Cl}^{-}$and $\mathrm{Na}^{+}$current activity, voltage-dependent $\mathrm{K}^{+}$current changes take place alongside oocyte maturation; these changes were considered relevant for a successful fertilization (Taglietti et al., 1984). Subsequently, by accurate electrophysiological recording in Rana perezi three different types of $\mathrm{Cl}^{-}$currents were characterized during oocyte growth (Ivorra and Morales 1997) relating them to a definite functional role in the maturation process. Along with the main currents described, the occurrence of a voltage-dependent hydrogen current in the Ambistoma immature oocytes was first reported (Barish and Baud 1984).

In the membrane of full-grown frog oocytes (Taglietti etal., 1983), two kinds of voltage-dependent currents were described, the first was aspecific and activated by hyperpolarizing steps more negative than $-90 \mathrm{mV}$ and the second was a cationic channel activated by depolarizing steps to potentials more positive than $+40 \mathrm{mV}$. Since they were related to the inward and outward rectification of the intensity/voltage relationship, authors suggested that their function was to maintain the membrane potential at a constant value. An accurate electrophysiological characterization of the presence and properties of endogenous stretch-activated ion currents was performed in Xenopus mature oocytes, however no correlation with reproductive events was further suggested (Yang and Sachs 1990). Subsequently it was hypothesized a functional role of mechanosensitive cation-selective currents of Xenopus oocytes in the fertilization process (Lane et al., 1991) since the inhibition of mechanically gated cation currents resulted in the reduction of the success of fertilization and the increased mortality in developing embryos (Wilkinson et al., 1998). The involvement of cation channels in the physiology of Xenopus oocytes have been also confirmed by other authors who, studying the effect of maitotoxin, suggested the presence of a nonselective cation conductance possibly involved in changes of the membrane potential that occur during the early stages of fertilization (Bielfeld-Ackermann et al., 1998). Recordings of $\mathrm{Ca}^{2+}$-activated $\mathrm{Cl}^{-}$currents and store-operated $\mathrm{Ca}^{2+}$ current activities in Xenopus were also suggested to play a role along with maturation promoting factor in the uncoupling between intracellular $\mathrm{Ca}^{2+}$ releasing and capacitative $\mathrm{Ca}^{2+}$ entry (Marin 2012).

In mammals, oocyte maturation is accompanied by relevant ion currents activities. In bovine immature oocytes the activity of two-pore $\mathrm{K}^{+}$currents participate to set the membrane potential and appear to contribute to the electrical activities of the plasma membrane during oocyte maturation (Hur et al., 2009).

ATP-sensitive $\mathrm{K}^{+}$currents have been seen to regulate membrane potential affecting in the meantime, intracellular $\mathrm{Ca}^{2+}$ levels (Nichols 2006). These currents have been found in human, bovine and porcine oocytes at various maturational stages (Du et al., 2010). The link established by these currents and intracellular metabolism, membrane excitability and intracellular $\mathrm{Ca}^{2+}$ signalling suggests a potential role to generate infertility due to the stress impact or metabolic diseases.

Voltage-dependent anion currents, which play a key role in mitochondrial metabolism, have been recently found on the membrane of porcine oocytes (Cassara et al., 2009), they appear to be arranged as ring-like clusters of structures distributed on the cortical area at the GV stage, however this is not the case at the mature metaphase II (MII) stage oocytes. Either their localization or their absence at the end of maturation suggests a functional role during maturation and fertilization of mammalian oocytes.

Since plasma membrane is also the site of fluid movements between the inner and outer compartments of the cell, the water flow moves across the membrane either for simple diffusion or by means of ion channels (Verkman et al., 1996). Aquaporins (AQPs) are a family of small membrane channel proteins that are expressed in plasma membranes of many cell types involving fluid transport (Carbrey and Agre 2009). In mouse oocytes, the Aqp3 mRNA is expressed in immature oocytes and decreases after either in vitro or in vivo maturation (Jo et al., 2011) suggesting a function of these channels in underlying correct maturation progress. In addition, experiments aimed to improve oocyte vitrification, confirmed a role of AQP3 in immature oocytes (Yamaji et al., 2011).

The role of $\mathrm{Ca}^{2+}$ in oocyte maturation is still a matter of debate (Boni et al., 2007). A wide body of literature deals on the role of 
$\mathrm{IP}_{3}$-induced $\mathrm{Ca}^{2+}$ release through $\mathrm{IP}_{3}$ receptors during meiotic maturation, suggesting that this could be among the mechanisms underlying maturation of bovine oocytes. A minor role is instead attributed to $\mathrm{Ca}^{2+}$ release through ryanodine receptors, which are poorly expressed in bovine oocytes (He et al., 1997). In the hamster and mouse, a series of spontaneous $\mathrm{Ca}^{2+}$ oscillations occur when oocyte are isolated from the follicle up to the GVBD stage (Carroll et al., 1994; Fujiwara et al., 1993), thereafter $\mathrm{Ca}^{2+}$ seems to not affect further meiotic progression. In bovine and pig, no $\mathrm{Ca}^{2+}$ oscillations occur during meiotic progression; although it has been shown that $\mathrm{Ca}^{2+}$ ionophore exposure induces meiosis resumption in oocytes arrested either at the GV (Wasserman and Masui 1975) or MIl stage (Boni et al., 2002).

Since extracellular $\mathrm{Ca}^{2+}$ is required for in vitro GVBD, meiosis progression (De Felici and Siracusa 1982; He et al., 1997; Homa 1991) and the first meiotic division (Paleos and Powers 1981), $\mathrm{Ca}^{2+}$ ion transport through the plasma membrane seems to play a functional role in maturation. Electrophysiological and pharmacological characterization of ion currents underlying bovine oocyte maturation showed a predominant role of L-type $\mathrm{Ca}^{2+}$ currents (Tosti et al., 2000), that however decrease throughout meiosis progression. Also in mouse oocytes, the activity of L-type $\mathrm{Ca}^{2+}$ currents have been demonstrated to underlay meiosis resumption (Murnane et al., 1988) and to increases after puberty (Murnane and DeFelice 1993), suggesting a role for these currents in the acquisition of meiotic competence.

Recently, plasma membrane-resident $\mathrm{Ca}^{2+}$ channel proteins (STIM1 and Orai1) responsible for mediating $\mathrm{Ca}^{2+}$ entry after the mobilization of intracellular $\mathrm{Ca}^{2+}$, have been identified in pig and mouse oocytes and their involvement in store-operated $\mathrm{Ca}^{2+}$ entry has also been demonstrated (Gomez-Fernandez et al., 2009; Koh et al., 2009; Yu et al., 2009). Their up regulation has been shown to induce a dramatic increase in $\mathrm{Ca}^{2+}$ entry after intracellular store depletion. Interestingly, in pig Orai1 expression decreases during oocyte maturation (Wang et al., 2012) whereas its down regulation inhibit $\mathrm{Ca}^{2+}$ influx after store depletion and the $\mathrm{Ca}^{2+}$ oscillations induced by the fertilizing sperm. On the other hand up regulation of Orai1 in the oocytes also modifies store-operated $\mathrm{Ca}^{2+}$ entry and plays an inhibitory effect on the fertilization $\mathrm{Ca}^{2+}$ signal, that results moreover in a long term negative effect on following embryo development.

In humans, the first studies on membrane potential have been performed by intracellular electrical recordings in immature oocytes collected by ovariectomy (Dolci et al., 1985). Using the same electrophysiological technique, Feichtinger et al., tested membrane potential variations in oocytes collected at different stages of maturation (Feichtinger et al., 1988). Subsequently patch-clamp and whole-cell recordings were first applied in immature and mature oocytes. In the latter, the most frequently observed channel was a 60 picoSiemens non-inactivating, $\mathrm{K}^{+}$selective pore which was activated by depolarization (DeFelice et al., 1988).

\section{The spermatozoon}

The spermatozoon is a highly specialized cell whose aim is to transport the genome into the oocyte and to trigger the oocyte into metabolic activation. In order to become competent for oocyte activation, the spermatozoon undergoes a series of changes in either its morphology or metabolism. Most of these processes are however accompanied by modifications in the electrical properties of the plasma membrane. Literature reports an increasing evidence that ion currents play a role in sperm physiology (Darszon et al., 2001; Darszon et al., 1999; Darszon et al., 2008; Lishko et al., 2012). By using an innovative technique of the patch-clamp applied to monolayers generated from a lipid vesicles and isolated sperm membranes, it was possible for the first time to record the ion current activity on the sea urchin sperm plasma membrane (Lievano et al., 1985). Subsequently, this technique was applied to spermatozoa from other animal models reporting that main ion currents on the sperm plasma membrane were cations $\left(\mathrm{K}^{+}\right.$and $\mathrm{Ca}^{2+}$ ) and anion $(\mathrm{Cl})$ currents (Chan et al., 1997; Kirichok and Lishko 2006; Lishko et al., 2013; Navarro et al., 2008).

Immature male germ cells were specifically suitable for electrophysiological recordings since they are round and larger than the mature spermatozoa but also because they may express some of the proteins present on the plasma membrane of mature spermatozoon.

Earlier studies showed the presence $\mathrm{K}^{+}$and $\mathrm{Ca}^{2+}$ currents in rat spermatogenetic cells (Hagiwara and Kawa 1984), following investigation on rat spermatids suggested that $\mathrm{Cl}^{-}, \mathrm{K}^{+}$and at a lesser extent $\mathrm{Na}^{+}$conductances were possible responsible for a negative membrane potential recorded (Reyes et al., 1994). Subsequent studies highlighted a role for $\mathrm{Cl}^{-}$conductance in spermatogenesis in Caenorhabditis elegans in fact a new inwardly rectifying $\mathrm{Cl}$ - channel was characterized and put forward as an important candidate in the spermatid differentiation (Machaca et al., 1996).

In mouse spermatogenetic cells, Santi et al., documented a pHdependent $\mathrm{Ca}^{2+}$ permeability and a series of $\mathrm{K}^{+}$selective currents correlating them with function of mature spermatozoa (Santi et al., 1998). In particular, $\mathrm{Ca}^{2+}$ was correlated to the $\mathrm{Ca}^{2+}$ influx required for initiating the acrosome reaction (AR) at the time of first binding whereas $\mathrm{K}^{+}$currents were related to the hyperpolarization occurring for sperm fertilization competence (Felix et al., 2002; MunozGaray et al., 2001). The discovery of the expression of functional T-type $\mathrm{Ca}^{2+}$ channels during mouse spermatogenesis (Arnoult et al., 1999; Son et al., 2002) suggested an important role of these currents in the fertility block caused by contraceptive substances (Bai and Shi 2002).

The findings on immature sperm cells clearly showed an involvement of ion currents in either sperm production and function. In particular, the process that transforms the immature quiescent sperm in a cell competent for fertilization is the sperm activation, a process which is induced by the contact with the extracellular investments of the oocyte that clearly relies on the activity of ion currents.

Among the steps that allow sperm activation, chemotaxis is the attraction of motile sperm towards the oocyte after first chemical signals or binding of the gametes. Earlier studies on sea urchin spermatozoa showed that these cells are quiescent in the testis due to high $\mathrm{K}^{+}$concentration, $\mathrm{pH}$, and oxygen tension, for review see (Tosti 1994). After spawning in the environment, changes in these parameters induced motility of spermatozoa. Subsequent studies demonstrated the latter involved sperm ion currents activity (Morisawa 1994). In fact, in echinoderms the compounds released from extracellular oocyte coat were able to induce ion fluxes and in turn a modulation of second messengers. Induction of sperm motility was shown to be essentially accompanied by $\mathrm{K}^{+}$currents modulation (Lee and Garbers 1986; Lievano et al., 1985), whereas following studies showed that $\mathrm{K}^{+}$efflux at spawning generated a 
cascade of other electrical events such as hyperpolarization of the membrane potential, $\mathrm{Na}^{+} / \mathrm{H}^{+}$exchange, $\mathrm{Na}^{+}$influx, depolarization of membrane potential and at last $\mathrm{Ca}^{2+}$ currents, for review see (Darszon et al., 2001). The finding of a cation current activity and sperm-activating peptides (SAPs) in the flagellum were then strictly related to the initial hyperpolarization associating it to the flagellar movements and to regulation of sperm trajectory respectively (Darszon et al., 2008; Gauss et al., 1998).

Also in other species sperm chemotaxis involving ion currents activity was described. In ascidians the initial observations of Miller (1975) were subsequently corroborated by other authors who showed the involvement of a $\mathrm{K}^{+}$permeability increase at contact point of sperm and oocyte followed by the hyperpolarization of the sperm plasma membrane which in turn mobilizes CAMP, a cAMPdependent kinases that then activate sperm motility (Izumi et al., 1999). Furthermore in ascidians the cascade of cAMP elevation were found to activate T- type $\mathrm{Ca}^{2+}$ currents (Yoshida et al., 1994).

The role of $\mathrm{K}^{+}$currents was also demonstrated to regulate sperm motility in fishes, in particular due to the reverse of external osmolarity at the spawning. Following these initial events, an intracellular $\mathrm{Ca}^{2+}$ rise was also shown to trigger the initiation of sperm motility in marine and freshwater teleosts, salmonid and rainbow trout (Oda and Morisawa 1993; Takai and Morisawa 1995; Tanimoto et al., 1994; Tanimoto and Morisawa 1988).

In mammals, the role of ion channels has been clearly demonstrated in chemotaxis, in fact some evidences indicating an involvement of intracellular $\mathrm{Ca}^{2+}$ release from stores in the mid-piece seems to mediate flagellar beating and, hence, chemotactic response.

The last basic event of sperm activation is the AR which is morphologically represented by the breakdown of the acrosomal vesicle that releasing its content allow the spermatozoon to exhibit a high fusible membrane (Florman et al., 2008; Garbers 1989). AR is also induced at the contact with the extracellular layer of the oocyte, and many different compounds have been shown to be responsible for AR induction (Alves et al., 1997; Ikadai and Hoshi 1981; Koyota et al., 1997). The AR is recognized to be regulated by ion current activities and in particular a $\mathrm{Ca}^{2+}$ influx is an absolute requirement for $A R$ in the sperm of all species studied so far (Darszon et al., 2001; Darszon et al., 1999; Florman et al., 2008). However experimental evidences supported also a role of $\mathrm{K}^{+}$currents in AR induction (Schackmann et al., 1978, Kazazoglou et al., 1985, Yanagimachi, 1994).

The involvement of ion currents in $\mathrm{AR}$ was demonstrated in the sea urchin where an immediate $\mathrm{Na}^{+}$and $\mathrm{Ca}^{2+}$ influx and $\mathrm{H}^{+}$and $\mathrm{K}^{+}$ efflux occur after the contact of oocyte jelly with a sperm receptor. These events also resulted in a change of membrane potential and an increase in $\mathrm{pH}$ due to a $\mathrm{Na}^{+} / \mathrm{H}^{+}$exchange and the intracellular $\mathrm{Ca}^{2+}$ rise (Darszon et al., 1999). Findings of two different $\mathrm{Ca}^{2+}$ currents along with $\mathrm{Cl}^{-}$selective currents acting in AR were also reported (Guerrero and Darszon 1989). As in marine animals, in mammalian sperm the contact of the sperm receptor with the oocyte envelope (zona pellucida) causes elevation of intracellular $\mathrm{Ca}^{2+}, \mathrm{pH}$ increase and a change in the membrane potential finally resulting in AR occurrence (Arnoult et al., 1999; Darszon et al., 2001; Florman et al., 1998; Osman et al., 1989).

An extensive literature on the presence of ion channels on the head of the mammalian spermatozoa, responsible for $\mathrm{Ca}^{2+}$ entry and intracellular $\mathrm{Ca}^{2+}$ rise, reports low and high voltage-activated, receptor-operated and store-operated $\mathrm{Ca}^{2+}$ currents (Benoff 1998;
Escoffier etal., 2007). Furthermore T-type voltage gated $\mathrm{Ca}^{2+}{ }^{+}$currents were shown to play a peculiar role in the generation of AR (Darszon et al., 1999; Darszon et al., 2006; Florman et al., 1998).

In human spermatozoa, along with the role of $\mathrm{Na}^{+}$currents activated by progesterone stimulus (Patrat et al., 2000), the existence of voltage gated $\mathrm{Ca}^{2+}$ currents was demonstrated (Linares-Hernandez et al., 1998), however their relation with the AR induction is still under investigation since the many indirect evidences reported (Darszon et al., 2011; Jagannathan et al., 2002). Among the mechanisms proposed for gating plasma membrane $\mathrm{Ca}^{2+}$ currents a capacitating $\mathrm{Ca}^{2+}$ entry mechanism play a relevant role. In fact in mouse spermatozoa, a $\mathrm{Ca}^{2+}$ influx generated by the depletion of $\mathrm{Ca}^{2+}$ stores was shown (O'Toole et al., 2000). Following studies (Rossato et al., 2001) suggested that $\mathrm{Ca}^{2+}$ stores depletion may be responsible for a double process: i) gating of $\mathrm{Ca}^{2+}$ activated $\mathrm{K}^{+}$currents, with $\mathrm{K}^{+}$efflux causing a hyperpolarization of membrane potential and ii) the capacitative gating of voltage-gated $\mathrm{Ca}^{2+}$ currents, with a subsequent depolarization of the plasma membrane. In the early 2000' it was reported that spermatozoa possess aspecific cation channel named CatSper (cation channel of spermatozoa), whose function seems to activate sperm motility. CatSper is a novel type of $\mathrm{Ca}^{2+}$ channel and the first member, CatSper1, was detected in mouse during searches for sequence homology to the voltage-gated $\mathrm{Ca}^{2+}$ channels (Ren et al., 2001). Subsequently other 3 members of the family were discovered by means of molecular biology techniques CatSper 2, 3 and 4. These four CatSper proteins showed low identity with those found in all mammals examined, included human, the ascidian Ciona intestinalis and the sea urchin Strongylocentrotus purpuratus. Studies on the role and function of CatSper showed that it is one of the major $\mathrm{Ca}^{2+}$ conducting channel in spermatozoa (Darszon et al., 2011) and that its role is strictly related to male infertility and in particular to sperm motility (Qi et al., 2007; Singh and Rajender 2015; Williams et al., 2015). This hypothesis was also corroborated by the fact that this current originated from the principal piece of the sperm flagellum where CatSper1 protein is located (Lishko and Kirichok 2010).

SLO3 is the high-conductance $\mathrm{K}^{+}$channel expressed only in mammalian testes, which is involved in multiple mechanisms of male fertility (Mannowetz et al., 2013; Santi et al., 2010) since it has been recognized to be responsible for capacitation-induced hyperpolarization and membrane hyperpolarization which is crucial for the AR. Many authors consider the SLO3 channel a putative candidate for a male contraceptive drug since Slo3 null mice are unable to perform progressive motility and to undergo the AR. Avery recent report shows in mouse spermatozoa a possible functional connection between CatSper, SLO3, and transient receptor potential channel family members since the genetic deletion of either of those channels results in mouse male infertility (Chavez et al., 2014).

An hypothesis that anions were involved in the mammalian AR (Morales et al., 1993) was supported by electrophysiological studies that found different types of $\mathrm{Cl}^{-}$channels with different conductance on the sperm head (Bai and Shi 2001) and by previous experimental evidence that mouse sperm $\mathrm{Cl}^{-}$channels participate in the AR induced by the zona pellucida in mammals (Espinosa et al., 1998; Sato et al., 2000).

\section{First electrical events at fertilization}

Main steps of reproduction are the production of gametes (ga- 
metogenesis), their maturation, reciprocal activation and at last their interaction that is widely recognized to be the key event of all the process.

Although it is different along the species studied, one of the earliest event of fertilization, is the electrical change of the oocyte plasma membrane. In the 50' a transient change in the membrane potential was described at fertilization and named as fertilization potential (Hiramoto 1959; Oddo and Esposito 1951). Nonetheless fertilization potential was described in oocytes of several marine animals (Dale et al., 1978; Dale and de Santis 1981; David et al., 1988; Lansman 1983; Sato et al., 2000) only after the advent of the whole-cell voltage clamp technique, it was shown that these electrical modifications were due to a ion flux (the fertilization currentFC) across the plasma membrane. In 1984, Dale and De Felice in ascidian oocytes first characterized this current showing that $F C$ is generated by the gating a peculiar population of ion channels in the newly fertilized oocyte (Dale 1994; Dale and De Felice 1984); (Tosti and Boni 2004) which in turn depolarized the membrane potential.

The characterization of the fertilization channels demonstrated that they are large, non-specific with a single conductance of 400 picoSiemens (Dale and De Felice 1984). In other ascidian species at fertilization a role of voltage-gated $\mathrm{Ca}^{2+}$ currents was shown in Phallusia mammillata (Goudeau and Goudeau 1993) and the appearance of a inward rectifying $\mathrm{Cl}^{-}$current was described in Boltenia villosa (Coombs et al., 1992).

In 1998, De Simone et al., recorded in whole-cell voltage clamped sea urchin oocytes an inward $\mathrm{Ca}^{2+}$-dependent FC demonstrating that it is driven by non-specific ion channels (De Simone et al., 1998). In several amphibian species it was established that $\mathrm{Cl}^{-}$channels in the oocytes are responsible for the fertilization potential (Jaffe and Schlichter 1985; Webb and Nuccitelli 1985), however a fertilization current which is at the basis of the fertilization potential in Xenopus oocytes was recorded only later on (Glahn and Nuccitelli 2003). This inward current resembled the ones recorded in the marine invertebrates. A careful characterization showed that the FC is underlied by the $\mathrm{Ca}^{2+}$-activated $\mathrm{Cl}^{-}$channels.

In mammals, first signs of electrical events at fertilization were a series of hyperpolarization that accompanied the sperm entry (Igusa et al., 1983) showing the difference between mammalian and invertebrate oocytes. Subsequent studies aimed to record FC in mammalian oocytes (Gianaroli et al., 1994; Miyazaki 1988; Tosti et al., 2002) further highlighted such differences in the FC; in fact in human oocytes the FC is not the first event but it is generated by a $\mathrm{Ca}^{2+}$ release which in turn activate $\mathrm{K}^{+}$channels generating the outward current (Dale et al., 1996).

The latter is also accompanied by a change in the oocyte membrane potential which transiently hyperpolarizes in all the mammalian oocytes. The function of these electrical events is still to be clarified in most of the cases, however Tosti et al., associated the FC in the ascidian Ciona intestinalis with a long term effect on the embryo development (Tosti etal., 2003) and a $\mathrm{Ca}^{2+}$-activated outward current following cytosolic sperm factor injection was observed relating it to a signal for oocyte activation (Homa and Swann 1994).

\section{Conclusion}

In 1991, Neher and Sackman were awarded with the Nobel prize for the invention of the patch clamp technique. This proved the huge importance of the study of the ion channel activity that was initially applied to neurobiology (Parkinson), neuromuscular function and channelopathies (cystic fibrosis). The patch clamp technique has been subsequently used to clarify some mechanisms at the basis of the reproductive process. In this review we have provided an overview of the involvement of ion currents activities in the gametes physiology and the early events of fertilization, showing that ion currents are present from gametogenesis up to the embryo development and play a key role in the cell physiology and functionality of the related processes.

In the last 15 years, it has been claimed a decline in human fertility (Yoldemir and Oral 2012) and there is also an evidence of worrying decrease of some key species endangered by the environmental stress (Clulow et al., 2014). So it is clearly evident the need to develop new techniques useful to improve in vitro maturation and fertilization; these are important reproductive technologies aimed to generates mature gametes capable of supporting embryo development and full development of the offspring.

The knowledge of the mechanisms governed by ion current activities may represent clinical and commercial incentive to improve the efficiency of these technologies in order to protect and increase the fertility of threatened animal species and human. Least but not last, ion current manipulation in gametes is a highly promising target to formulate new and soft non-hormonal contraceptive techniques.

Acknowledgments

We thank Dr. F. Formisano for art and computer graphics.

\section{References}

ALVES A P, MULLOY B, DINIZ J A, MOURAO P A (1997). Sulfated polysaccharides from the egg jelly layer are species-specific inducers of acrosomal reaction in sperms of sea urchins. J Biol Chem 272: 6965-6971.

ARNOULT C, KAZAM I G, VISCONTI P E, KOPF G S, VILLAZ M, FLORMAN H M (1999). Control of the low voltage-activated calcium channel of mouse sperm by egg ZP3 and by membrane hyperpolarization during capacitation. Proc Natl Acad Sci USA 96: 6757-6762.

BAI J P, SHI Y L (2001). A patch-clamp study on human sperm $\mathrm{Cl}^{-}$channel reassembled into giant liposome. Asian J Andro/ 3: 185-191.

BAI J P, SHI Y L (2002). Inhibition of $\mathrm{Ca}^{2+}$ channels in mouse spermatogenic cells by male antifertility compounds from Tripterygium wilfordii Hook. f. Contraception 65: 441-445.

BARISH M E (1983). A transient calcium-dependent chloride current in the immature Xenopus oocyte. J Physiol 342: 309-325.

BARISH M E, BAUD C (1984). A voltage-gated hydrogen ion current in the oocyte membrane of the axolotl, Ambystoma. J Physiol 352: 243-263.

BAUD C (1983). Developmental change of a depolarization-induced sodium permeability in the oocyte of Xenopus laevis. Dev Biol 99: 524-528.

BENOFF S (1998). Voltage dependent calcium channels in mammalian spermatozoa. Front Biosci 3: D1220-1240.

BIELFELD-ACKERMANNA, RANGE C, KORBMACHER C (1998). Maitotoxin (MTX) activates a nonselective cation channel in Xenopus laevis oocytes. Pflügers Archiv 436: 329-337.

BLOCK M L, MOODY W J (1987). Changes in sodium, calcium and potassium currents during early embryonic development of the ascidian Boltenia villosa. $J$ Physiol 393: 619-634.

BONI R, CUOMO A, TOSTI E (2002). Developmental potential in bovine oocytes is related to cumulus-oocyte complex grade, calcium current activity, and calcium stores. Biol Reprod 66: 836-842.

BONI R, GUALTIERI R, TALEVI R, TOSTI E (2007). Calcium and other ion dynamics during gamete maturation and fertilization. Theriogenology68 Suppl 1: S156-164

BOSMA M M, MOODY W J (1990). Marcroscopic and single-channel studies of two $\mathrm{Ca}^{2+}$ channel types in oocytes of the ascidian Ciona intestinalis. J Membr Biol 
114: $231-243$

BOURINET E, NARGEOT J, CHARNET P (1992). Electrophysiological characterization of a TTX-sensitive sodium current in native Xenopus oocytes. Proc Biol Sci 250: 127-132.

CARBREY J M, AGRE P (2009). Discovery of the aquaporins and development of the field. Handb Exp Pharmacol: 3-28.

CARROLL J, SWANN K, WHITTINGHAM D, WHITAKER M (1994). Spatiotemporal dynamics of intracellular $\mathrm{Ca}^{2+}$ oscillations during the growth and meiotic maturation of mouse oocytes. Development 120: 3507-3517.

CASSARA M C, MENZEL V A, HINSCH K D, WRENZYCKI C, HINSCH E (2009). Voltage-dependent anion channels 1 and 2 are expressed in porcine oocytes. Biosci Rep 30: 193-200.

CHAMBERS E L (1989). Fertilization in voltage-clamped sea urchin eggs. In Mechanisms of egg activation (Nuccitelli, R., Cherr, G.N. and Clark, W.H. Jr., Eds.). Plenum Press, New York, pp 1-8.

CHAN H C, ZHOU T S, FU W O, WANG W P, SHI Y L, WONG P Y (1997). Cation and anion channels in rat and human spermatozoa. Biochim Biophys Acta 1323: 117-129.

CHAVEZ J C, FERREIRA J J, BUTLER A, DE LA VEGA BELTRAN J L, TREVINO C L, DARSZONA, SALKOFF L, SANTI C M (2014). SLO3 K+ channels control calcium entry through CATSPER channels in sperm. J Biol Chem 289: 32266-32275.

CLULOW J, TRUDEAU V L, KOUBA A J (2014). Amphibian declines in the twentyfirst century: why we need assisted reproductive technologies. Adv Exp Med Biol 753: 275-316.

COLAS P, DUBE F (1998). Meiotic maturation in mollusc oocytes. Semin Cell Dev Biol 9: 539-548.

COOMBS J L, VILLAZM, MOODYWJ (1992). Changes in voltage-dependent ion currents during meiosis and first mitosis in eggs of an ascidian. Dev Biol 153:272-282.

CUOMO A, DI CRISTO C, PAOLUCCI M, DI COSMO A, TOSTI E (2005). Calcium currents correlate with oocyte maturation during the reproductive cycle in Octopus vulgaris. J Exp Zool A Comp Exp Biol 303: 193-202.

CUOMO A, SILVESTRE F, DE SANTIS R, TOSTI E (2006). $\mathrm{Ca}^{2+}$ and $\mathrm{Na}^{+}$current patterns during oocyte maturation, fertilization, and early developmental stages of Ciona intestinalis. Mol Reprod Dev 73: 501-511.

DALE B (1994). Oocyte activation in invertebrates and humans. Zygote 2: 373-377.

DALE B, DE FELICE L (1984). Sperm-activated channels in ascidian oocytes. Dev Biol 101: 235-239.

DALE B, DE FELICE L J, TAGLIETTI V (1978). Membrane noise and conductance increase during single spermatozoon-egg interactions. Nature 275: 217-219.

DALE B, DE SANTIS A (1981). Maturation and fertilization of the sea urchin oocyte: an electrophysiological study. Dev Biol 85: 474-484.

DALE B, FORTUNATO A, MONFRECOLA V, TOSTI E (1996). A soluble sperm factor gates $\mathrm{Ca}^{2+}$-activated $\mathrm{K}^{+}$channels in human oocytes. J Assist Reprod Genet 13: $573-577$.

DALE B, TALEVI R, DEFELICE L J (1991). L-type $\mathrm{Ca}^{2+}$ currents in ascidian eggs. Exp Cell Res 192: 302-306

DARSZON, A, BELTRAN C, FELIX R, NISHIGAKI T, TREVINO C L (2001). Ion transport in sperm signaling. Dev Biol 240: 1-14.

DARSZON, A, GUERRERO A, GALINDO B E, NISHIGAKI T, WOOD C D (2008). Sperm-activating peptides in the regulation of ion fluxes, signal transduction and motility. Int. J. Dev. Biol. 52: 595-606.

DARSZON, A, LABARCA P, NISHIGAKI T, ESPINOSA F (1999). Ion channels in sperm physiology. Physiol Rev 79: 481-510.

DARSZON, A, LOPEZ-MARTINEZP,ACEVEDO JJ, HERNANDEZ-CRUZA, TREVINO $\mathrm{C} L$ (2006). T-type $\mathrm{Ca}^{2+}$ channels in sperm function. Cell Calcium 40: 241-252.

DARSZON, A, NISHIGAKI T, BELTRAN C, TREVINO C L (2011). Calcium channels in the development, maturation, and function of spermatozoa. Physiol Rev 91: 1305-1355.

DAVID C, HALLIWELL J, WHITAKER M (1988). Some properties of the membrane currents underlying the fertilization potential in sea urchin eggs. J Physiol 402: 139-154.

DE FELICI M, SIRACUSA G (1982). Survival of isolated, fully grown mouse ovarian oocytes is strictly dependent on external $\mathrm{Ca}^{2+}$. Dev Biol 92: 539-543.

DE SIMONE M L, GRUMETTO L, TOSTIE, WILDING M, DALE B (1998). Non-specific currents at fertilisation in sea urchin oocytes. Zygote 6: 11-15.

DEFELICE L, MAZZANTI M, MURNANE J, COHEN J (1988). Patch-clamp and whole-cell recording from human oocytes. Biophys J 53: A547-A547.

DEFELICE L J (Ed.) (1997). Electrical properties of cells: patch clamp for biologists. Springer, Germany.

DOLCI S, EUSEBI F, SIRACUSA G (1985). Gamma-Amino butyric-N-acid sensitivity of mouse and human oocytes. Dev Biol 109: 242-246.

DU Q, JOVANOVIC S, SUKHODUB A, BARRATT E, DREW E, WHALLEY K M KAY V, MCLAUGHLIN M, TELFER E E, BARRATT C L, JOVANOVIC A (2010). Human oocytes express ATP-sensitive $\mathrm{K}^{+}$channels. Hum Reprod 25: 2774-2782.

DUBE F (1992). Thapsigargin induces meiotic maturation in surf clam oocytes Biochem Biophys Res Commun 189: 79-84.

DUPONT G, HEYTENS E, LEYBAERT L (2010). Oscillatory Ca2+ dynamics and cell cycle resumption at fertilization in mammals: a modelling approach. Int. J. Dev. Biol. 54: 655-665.

ESCOFFIER J, BOISSEAU S, SERRES C, CHEN C C, KIM D, STAMBOULIAN S, SHIN H S, CAMPBELL K P, DE WAARD M, ARNOULT C (2007). Expression, localization and functions in acrosome reaction and sperm motility of $\mathrm{Ca}(\mathrm{V}) 3.1$ and $\mathrm{Ca}(\mathrm{V}) 3.2$ channels in sperm cells: an evaluation from $\mathrm{Ca}(\mathrm{V}) 3.1$ and $\mathrm{Ca}(\mathrm{V}) 3.2$ deficient mice. J Cell Physiol 212: 753-763.

ESPINOSA F, DE LA VEGA-BELTRAN J L, LOPEZ-GONZALEZ I, DELGADO R LABARCA P, DARSZON A (1998). Mouse sperm patch-clamp recordings revea single $\mathrm{Cl}^{-}$channels sensitive to niflumic acid, a blocker of the sperm acrosome reaction. FEBS Lett 426: 47-51.

FEICHTINGER W, OSTERODE W, HOYER J (1988). Membrane potential measurements in human oocytes. Arch Gynecol Obstet 243: 123-129.

FELIX R, SERRANO C J, TREVINO C L, MUNOZ-GARAY C, BRAVO A, NAVARRO A, PACHECO J, TSUTSUMI V, DARSZON A (2002). Identification of distinct $\mathrm{K}^{+}$ channels in mouse spermatogenic cells and sperm. Zygote 10: 183-188.

FLORMAN H M, ARNOULT C, KAZAM I G, LI C, O'TOOLE C M (1998). A perspective on the control of mammalian fertilization by egg-activated ion channels in sperm a tale of two channels. Biol Reprod 59: 12-16.

FLORMAN H M, JUNGNICKEL M K, SUTTON KA (2008). Regulating the acrosome reaction. Int J Dev Biol 52: 503-510.

FUJIWARA T, NAKADA K, SHIRAKAWA H, MIYAZAKI S (1993). Development of inositol trisphosphate-induced calcium release mechanism during maturation of hamster oocytes. Dev Biol 156: 69-79.

GALLO A, RUSSO G L, TOSTI E (2013). T-type $\mathrm{Ca}^{2+}$ current activity during oocyte growth and maturation in the ascidian Styela plicata. PLoS One 8: e54604

GARBERSD L(1989). Molecular basis of fertilization. Annu Rev Biochem 58: 719-742.

GAUSS R, SEIFERT R, KAUPP U B (1998). Molecular identification of a hyperpolarization-activated channel in sea urchin sperm. Nature 393: 583-587.

GIANAROLI L, TOSTI E, MAGLI C, IACCARINO M, FERRARETTI A P, DALE B (1994). Fertilization current in the human oocyte. Mol Reprod Dev 38: 209-214.

GILLOT I, PAYAN P, GIRARD J, SARDET C (1990). Calcium in sea urchin egg during fertilization. Int. J. Dev. Biol. 34: 117-125

GLAHN D, NUCCITELLI R (2003). Voltage-clamp study of the activation currents and fast block to polyspermy in the egg of Xenopus laevis. Dev Growth Differ 45: 187-197

GOMEZ-FERNANDEZ C, POZO-GUISADO E, GANAN-PARRA M, PERIANES M J, ALVAREZ I S, MARTIN-ROMERO F J (2009). Relocalization of STIM1 in mouse oocytes at fertilization: early involvement of store-operated calcium entry. Reproduction 138: 211-221.

GOUDEAU M, GOUDEAU H (1993). In the egg of the ascidian Phallusia mammillata, removal of external $\mathrm{Ca}^{2+}$ modifies the fertilization potential, induces polyspermy, and blocks the resumption of meiosis. Dev Biol 160: 165-177.

GUERRERO A, DARSZON A (1989). Evidence for the activation of two different $\mathrm{Ca}^{2+}$ channels during the egg jelly-induced acrosome reaction of sea urchin sperm. $J$ Biol Chem 264: 19593-19599.

GUERRIER P, LECLERC-DAVID C, MOREAU M (1993). Evidence for the involvement of internal calcium stores during serotonin-induced meiosis reinitiation in oocytes of the bivalve mollusc Ruditapes philippinarum. Dev Biol 159: 474-484.

HAGIWARA S, JAFFE LA (1979). Electrical properties of egg cell membranes. Annu Rev Biophys Bioeng 8: 385-416. 
HAGIWARA S, KAWA K (1984). Calcium and potassium currents in spermatogenic cells dissociated from rat seminiferous tubules. J Physiol 356: 135-149.

HE C L, DAMIANI P, PARYS J B, FISSORE R A (1997). Calcium, calcium release receptors, and meiotic resumption in bovine oocytes. Biol Reprod 57: 1245-1255.

HIRAMOTO Y (1959). Changes in electric properties upon fertilization in the sea urchin egg. Exp Cell Res 16: 421-424.

HOMA S T (1991). Neomycin, an inhibitor of phosphoinositide hydrolysis, inhibits the resumption of bovine oocyte spontaneous meiotic maturation. $J$ Exp Zool 258: 95-103.

HOMA S T, SWANN K (1994). A cytosolic sperm factor triggers calcium oscillations and membrane hyperpolarizations in human oocytes. Hum Reprod 9: 2356-2361.

HUR C G, CHOE C, KIM G T, CHO S K, PARK J Y, HONG S G, HAN J, KANG D (2009). Expression and localization of two-pore domain $\mathrm{K}^{+}$channels in bovine germ cells. Reproduction 137: 237-244.

IGUSA Y, MIYAZAKI S, YAMASHITA N (1983). Periodic hyperpolarizing responses in hamster and mouse eggs fertilized with mouse sperm. J Physiol340: 633-647.

IKADAI H, HOSHI M (1981). Biochemical studies on the acrosome reaction of the starfish, Asterias amurensis I. Factors participating in the acrosome reaction. Dev Growth Differ 23: 73-80.

IVORRAI, MORALES A (1997). Membrane currents in immature oocytes of the Rana perezi frog. Pflugers Arch 434: 413-421.

IZUMI H, MARIAN T, INABA K, OKA Y, MORISAWA M (1999). Membrane hyperpolarization by sperm-activating and -attracting factor increases CAMP level and activates sperm motility in the ascidian Ciona intestinalis. Dev Biol 213: 246-256.

JAFFE LA, CROSS NL (1984). Electrical properties of vertebrate oocyte membranes. Biol Reprod 30: 50-54.

JAFFE LA, ROBINSON K R (1978). Membrane potential of the unfertilized sea urchin egg. Dev Biol 62: 215-228.

JAFFE L A, SCHLICHTER L C (1985). Fertilization-induced ionic conductances in eggs of the frog, Rana pipiens. J Physiol 358: 299-319.

JAGANNATHAN S, PUBLICOVER S J, BARRATT C L (2002). Voltage-operated calcium channels in male germ cells. Reproduction 123: 203-215.

JO J W, JEE B C, SUH C S, KIM S H, CHOI Y M, KIM J G, MOON S Y (2011). Effect of maturation on the expression of aquaporin 3 in mouse oocyte. Zygote 19: 9-14.

KIRICHOK Y, LISHKO P V (2006). Rediscovering sperm ion channels with the patchclamp technique. Mol Hum Reprod 17: 478-499.

KOH S, LEE K, WANG C, CABOT R A, MACHATY Z (2009). STIM1 regulates storeoperated $\mathrm{Ca}^{2+}$ entry in oocytes. Dev Biol 330: 368-376.

KOYOTA S, WIMALASIRI K M, HOSHI M (1997). Structure of the main saccharide chain in the acrosome reaction-inducing substance of the starfish, Asterias amurensis. J Biol Chem 272: 10372-10376.

LANE JW, MCBRIDE D, HAMILLO P (1991). Amiloride block of the mechanosensitive cation channel in Xenopus oocytes. J. Physiol. 441: 347-366.

LANSMAN J B (1983). Voltage-clamp study of the conductance activated at fertilization in the starfish egg. J Physiol 345: 353-372.

LECLERC C, GUERRIER P, MOREAU M (2000). Role of dihydropyridine-sensitive calcium channels in meiosis and fertilization in the bivalve molluscs Ruditapes philippinarum and Crassostrea gigas. Biol Cell 92: 285-299.

LEE HC, GARBERS D L (1986). Modulation of the voltage-sensitive $\mathrm{Na}^{+} / \mathrm{H}^{+}$exchange in sea urchin spermatozoa through membrane potential changes induced by the egg peptide speract. J Biol Chem 261: 16026-16032.

LIEVANO A, SANCHEZ J A, DARSZON A (1985). Single-channel activity of bilayers derived from sea urchin sperm plasma membranes at the tip of a patch-clamp electrode. Dev Biol 112: 253-257.

LINARES-HERNANDEZ L, GUZMAN-GRENFELL A M, HICKS-GOMEZ J J, GONZALEZ-MARTINEZ M T (1998). Voltage-dependent calcium influx in human sperm assessed by simultaneous optical detection of intracellular calcium and membrane potential. Biochim Biophys Acta 1372: 1-12.

LISHKO P, CLAPHAM D E, NAVARRO B, KIRICHOK Y (2013). Sperm patch-clamp. Methods Enzymol 525: 59.

LISHKO P V, KIRICHOK Y (2010). The role of Hv1 and CatSper channels in sperm activation. J Physiol 588: 4667-4672.

LISHKO P V, KIRICHOK Y, REN D, NAVARRO B, CHUNG J J, CLAPHAM D E (2012). The control of male fertility by spermatozoan ion channels. Annu Rev
Physiol 74: 453-475.

MACHACA K, DEFELICE L J, L'HERNAULT S W (1996). A novel chloride channel localizes to Caenorhabditis elegans spermatids and chloride channel blockers induce spermatid differentiation. Dev Biol 176: 1-16.

MANNOWETZ N, NAIDOO N M, CHOO S-A S, SMITH J F, LISHKO P V (2013). Slo1 is the principal potassium channel of human spermatozoa. Elife 2:e01009.

MARIN M (2012). Calcium signaling in Xenopus oocyte. In Calcium Signaling. Vol. 740. Springer, Netherlands, pp.1073-1094.

MILLER RL. (1975). Chemotaxis of the spermatozoa of Ciona intestinalis. Nature 254:244-245

MIYAZAKI S-I (1988). Fertilization potential and calcium transients in mammalian eggs. Dev Growth Differ 30: 603-610.

MIYAZAKI S I, OHMORI H, SASAKI S (1975a). Action potential and non-linear current-voltage relation in starfish oocytes. J Physiol 246: 37-54.

MIYAZAKI S I, OHMORI H, SASAKI S (1975b). Potassium rectifications of the starfish oocyte membrane and their changes during oocyte maturation. JPhysiol246:55-78.

MOODY W J (1985). The development of calcium and potassium currents during oogenesis in the starfish, Leptasterias hexactis. Dev Biol 112: 405-413.

MOODY W J, BOSMAM M (1985). Hormone-induced loss of surface membrane during maturation of starfish oocytes: differential effects on potassium and calcium channels. Dev Biol 112: 396-404

MOODY W J, LANSMAN J B (1983). Developmental regulation of $\mathrm{Ca}^{2+}$ and $\mathrm{K}^{+}$currents during hormone-induced maturation of starfish oocytes. Proc Natl Acad Sci USA 80: 3096-3100.

MORALES E, DE LA TORRE L, MOY G W, VACQUIER V D, DARSZON A (1993). Anion channels in the sea urchin sperm plasma membrane. Mol Reprod Dev 36: 174-182.

MOREAU M, CHEVALJ (1976). Electrical properties of the starfish oocyte membranes. J Physiol 72: 293-300.

MOREAU M, DAVID C, AZZI L (1990). Changes in membrane properties during invitro meiotic maturation of the limpet Patella vulgata. Int J Dev Bio/ 34: 441-451.

MOREAU M, GUERRIER P, VILAIN J (1985). Ionic regulation of oocyte maturation. Biol. Fert. 1: 299-345.

MOREAU M, LECLERC C, GUERRIER P (1996). Meiosis reinitiation in Ruditapes philippinarum (Mollusca): involvement of L-calcium channels in the release of metaphase I block. Zygote 4: 151-157.

MORISAWA M (1994). Cell signaling mechanisms for sperm motility. Zoolog Sci 11: 647-662.

MORRILL G A, ZIEGLER D (1980). $\mathrm{Na}^{+}$and $\mathrm{K}^{+}$uptake and exchange by the amphibian oocyte during the first meiotic division. Dev Biol 74: 216-223.

MUNOZ-GARAY C, DE LA VEGA-BELTRAN J L, DELGADO R, LABARCA P, FELIX $\mathrm{R}$, DARSZON A (2001). Inwardly rectifying $\mathrm{K}^{+}$channels in spermatogenic cells: functional expression and implication in sperm capacitation. Dev Biol234:261-274.

MURNANE J, DE FELICE L, COHEN J (1988). Development of ionic currents in mouse oocyte. J Cell Biol 107: 4664.

MURNANE J M, DEFELICE L J (1993). Electrical maturation of the murine oocyte: an increase in calcium current coincides with acquisition of meiotic competence. Zygote 1: 49-60.

NAVARRO B, KIRICHOK Y, CHUNG J-J, CLAPHAM D E (2008). Ion channels that control fertility in mammalian spermatozoa. Int. J. Dev. Biol. 52: 607-613.

NEHER E, SAKMANN B (1992). The patch clamp technique. Sci Am 266: 44-51.

NICHOLS C G (2006). KATP channels as molecular sensors of cellular metabolism. Nature 440: 470-476.

O'TOOLE C M, ARNOULT C, DARSZON A, STEINHARDT R A, FLORMAN H M (2000). $\mathrm{Ca}^{2+}$ entry through store-operated channels in mouse sperm is initiated by egg ZP3 and drives the acrosome reaction. Mol Biol Cell 11: 1571-1584.

ODAS, MORISAWAM (1993). Rises of intracellular $\mathrm{Ca}^{2+}$ and $\mathrm{pH}$ mediate the initiation of sperm motility by hyperosmolality in marine teleosts. Cell Motil Cytoskeleton 25: $171-178$

ODDO A M, ESPOSITO M (1951). Changes in the potassium content of sea urchin eggs on fertilization. J Gen Physiol 34: 285-293.

OKAMOTO H, TAKAHASHI K, YAMASHITA N (1977). lonic currents through the membrane of the mammalian oocyte and their comparison with those in the tunicate and sea urchin. J Physiol 267: 465-495. 
OSMAN RA, ANDRIAM L, JONESAD, MEIZELS (1989). Steroid induced exocytosis: the human sperm acrosome reaction. Biochem Biophys Res Commun 160:828-833.

OUADID-AHIDOUCH H (1998). Voltage-gated calcium channels in Pleurodeles oocytes: classification, modulation and functional roles. Zygote 6: 85-95.

PALEOS G A, POWERS R D (1981). The effect of calcium on the first meiotic division of the mammalian oocyte. J Exp Zool 217: 409-416.

PATRAT C, SERRES C, JOUANNET P (2000). Induction of a sodium ion influx by progesterone in human spermatozoa1. Biol Reprod 62: 1380-1386.

QI H, MORAN M M, NAVARRO B, CHONG J A, KRAPIVINSKY G, KRAPIVINSKY L, KIRICHOK Y, RAMSEY I S, QUILL T A, CLAPHAM D E (2007). All four CatSper ion channel proteins are required for male fertility and sperm cell hyperactivated motility. Proc Natl Acad Sci USA 104: 1219-1223.

REN D, NAVARRO B, PEREZ G, JACKSONAC, HSU S, SHIQ, TILLY J L, CLAPHAM D E (2001). A sperm ion channel required for sperm motility and male fertility. Nature 413: 603-609.

REYES J G, BACIGALUPO J, ARAYA R, BENOS D J (1994). Ion dependence of resting membrane potential of rat spermatids. J Reprod Fertil 102: 313-319.

REYES R, PULAKAT L, MILEDI R, MARTINEZ-TORRES A (2009). Mammalian AT2 receptors expressed in Xenopus laevis oocytes couple to endogenous chloride channels and stimulate germinal vesicle break down. Cell Physiol Biochem 24: 45-52.

ROSSATO M, DI VIRGILIO F, RIZZUTO R, GALEAZZI C, FORESTA C (2001). Intracellular calcium store depletion and acrosome reaction in human spermatozoa: role of calcium and plasma membrane potential. Mol Hum Reprod 7: 119-128.

SANTI C M, MARTINEZ-LOPEZ P, DE LA VEGA-BELTRAN J L, BUTLER A, ALISIO A, DARSZONA, SALKOFF L(2010). The SLO3 sperm-specific potassium channel plays a vital role in male fertility. FEBS Lett 584: 1041-1046.

SANTI C M, SANTOS T, HERNANDEZ-CRUZ A, DARSZON A (1998). Properties of a novel $\mathrm{pH}$-dependent $\mathrm{Ca}^{2+}$ permeation pathway present in male germ cells with possible roles in spermatogenesis and mature sperm function. J Gen Physiol 112: 33-53

SATO Y, SON J H, TUCKER R P, MEIZEL S (2000). The zona pellucida-initiated acrosome reaction: defect due to mutations in the sperm glycine receptor/ $\mathrm{Cl}^{-}$ channel. Dev Biol 227: 211-218.

SCHLICHTER L (1989). Ion channels in Rana pipiens oocytes: changes during maturation and fertilization. In Mechanisms of Egg Activation. (Nuccitelli, R, Cherr GN and Clark WH Jr., Eds.), Plenum Press, New York, pp 89-132.

SCHLICHTER L C (1983). Spontaneous action potentials produced by $\mathrm{Na}$ and $\mathrm{Cl}$ channels in maturing Rana pipiens oocytes. Dev Biol 98: 47-59.

SHEN S, STEINHARDT R A (1976). An electrophysiological study of the membrane properties of the immature and mature oocyte of the Batstar, Patiria miniata. Dev Biol 48: 148-162.

SILVESTRE F, CUOMO A, TOSTI E (2009). Ion current activity and molecules modulating maturation and growth stages of ascidian (Ciona intestinalis) oocytes. $\mathrm{Mol}$ Reprod Dev 76: 1084-1093.

SIMONCINI L, MOODY W J (1990). Changes in voltage-dependent currents and membrane area during maturation of starfish oocytes: species differences and similarities. Dev Biol 138: 194-201.

SINGH AP and RAJENDER S. (2015). CatSper channel, sperm function and male fertility. Reprod Biomed Online 30:28-38.

SON W Y, HAN C T, LEE J H, JUNG K Y, LEE H M, CHOO Y K (2002). Developmental expression patterns of alpha1 $\mathrm{H}$ T-type $\mathrm{Ca}^{2+}$ channels during spermatogenesis and organogenesis in mice. Dev Growth Differ 44: 181-190.

STEINHARDT R A, LUNDIN L, MAZIA D (1971). Bioelectric responses of the echinoderm egg to fertilization. Proc Natl Acad Sci USA 68: 2426-2430.

SWANN K, YU Y (2008). The dynamics of calcium oscillations that activate mammalian eggs. Int. J. Dev. Biol. 52: 585-594.

TAGLIETTI V, TANZI F, ROMERO R (1983). Electrophysiological study of frog eggs at different stages of development. III) lonic currents activated by intense hyperpolarization and depolarization of the oocyte at the final stage of vitellogenesis. Boll Soc Ital Biol Sper 59: 955-961.
TAGLIETTI V, TANZI F, ROMERO R, SIMONCINI L (1984). Maturation involves suppression of voltage-gated currents in the frog oocyte. J Cell Physiol 121:576-588.

TAKAI H, MORISAWA M (1995). Change in intracellular $\mathrm{K}^{+}$concentration caused by external osmolality change regulates sperm motility of marine and freshwater teleosts. J Cell Sci 108 (Pt 3): 1175-1181.

TANIMOTO S, KUDO Y, NAKAZAWAT, MORISAWAM (1994). Implication that potassium flux and increase in intracellular calcium are necessary for the initiation of sperm motility in salmonid fishes. Mol Reprod Dev 39: 409-414.

TANIMOTO S, MORISAWA M (1988). Roles for potassium and calcium channels in the initiation of sperm motility in rainbow trout. Dev Growth Differ 30: 117-124.

TOMKOWIAK M, GUERRIER P, KRANTIC S (1997). Meiosis reinitiation of mussel oocytes involves L-type voltage-gated calcium channel. J Cell Biochem64:152-160.

TOSTI E (1994). Sperm activation in species with external fertilisation. Zygote 2 359-361.

TOSTI E, BONI R (2004). Electrical events during gamete maturation and fertilization in animals and humans. Hum Reprod Update 10: 53-65.

TOSTI E, BONI R, CUOMO A (2000). $\mathrm{Ca}^{2+}$ current activity decreases during meiotic progression in bovine oocytes. Am J Physiol Cell Physiol 279: C1795-1800.

TOSTI E, BONI R, CUOMO A (2002). Fertilization and activation currents in bovine oocytes. Reproduction 124: 835-846.

TOSTI E, BONI R, GALLO A, SILVESTRE F (2013). Ion currents modulating oocyte maturation in animals. Syst Biol Reprod Med 59: 61-68.

TOSTI E, ROMANO G, BUTTINO I, CUOMO A, IANORAA, MIRALTO A (2003). Bioactive aldehydes from diatoms block the fertilization current in ascidian oocytes. Mol Reprod Dev 66: 72-80.

VERKMANAS, VAN HOEKAN, MAT, FRIGERIA, SKACHWR, MITRAA, TAMARAPPOOBK, FARINAS J (1996). Water transport across mammalian cell membranes. Am J Physiol 270: C12-30.

WANG C, LEE K, GAJDOCSI E, PAPP A B, MACHATY Z (2012). Orai1 mediates store-operated $\mathrm{Ca}^{2+}$ entry during fertilization in mammalian oocytes. Dev Biol 365: 414-423.

WASSERMAN W J, MASUI Y (1975). Initiation of meiotic maturation in Xenopus laevis oocytes by the combination of divalent cations and ionophore A23187. J Exp Zool 193: 369-375.

WEBB D J, NUCCITELLI R (1985). Fertilization potential and electrical properties of the Xenopus laevis egg. Dev Biol 107: 395-406.

WEBER W M (1999). Endogenous ion channels in oocytes of Xenopus laevis: recent developments. J Membr Biol 170: 1-12.

WILKINSON N, GAO F, HAMILL O (1998). Effects of mechano-gated cation channe blockers on Xenopus oocyte growth and development. J Membr Biol 165: 161-174.

WILLIAMS HL, MANSELL S, ALASMARI W, BROWN SG, WILSON SM, SUTTON KA, MILLER MR, LISHKO PV, BARRATT CL, PUBLICOVER SJ, MARTINS DA and SILVA S. (2015). Specific loss of CatSper function is sufficient to compromise fertilizing capacity of human spermatozoa. Hum Reprod (doi: 10.1093/ humrep/dev243)

YAMAJIY, SEKIS, MATSUKAWAK, KOSHIMOTO C, KASAIM, EDASHIGE K (2011). Developmental ability of vitrified mouse oocytes expressing water channels. $J$ Reprod Dev 57: 403-408.

YANAGIMACHIR (1994). Mammalian fertilization In The Physiology of Reproduction. (Knobil E and Neill JD eds.). 2nd Edition. Raven Press: New York, pp.pp. 189-317.

YANG X-C, SACHS F (1990). Characterization of stretch-activated ion channels in Xenopus oocytes. J Physiol 431: 103-122.

YOLDEMIR T, ORAL E (2012). Has fertility declined in recent decades? Curr Opin Obstet Gynecol 24: 119-126.

YOSHIDA M, INABA K, ISHIDA K, MORISAWA M (1994). Calcium and cyclic AMP mediate sperm activation, but $\mathrm{Ca}^{2+}$ alone contributes sperm chemotaxis in the ascidian, Ciona savignyi. Dev Growth Differ 36: 589-595.

YU F, SUN L, MACHACA K (2009). Orai1 internalization and STIM1 clustering inhibition modulate SOCE inactivation during meiosis. Proc Natl Acad Sci USA 106: 17401-17406 


\section{Further Related Reading, published previously in the Int. J. Dev. Biol.}

Egg activation in physiologically polyspermic newt eggs: involvement of IP3 receptor, PLCy, and microtubules in calcium wave induction

Tomoyo Ueno, Takehiro Ohgami, Yuichirou Harada, Shuichi Ueno and Yasuhiro Iwao

Int. J. Dev. Biol. (2014) 58: 315-323

Visualization, characterization and modulation of calcium signaling during the development of slow muscle cells in intact zebrafish embryos

Chris Y. Cheung, Sarah E. Webb, Donald R. Love and Andrew L. Miller

Int. J. Dev. Biol. (2011) 55: 153-174

Could modifications of signalling pathways activated after ICSI induce a potential risk of epigenetic defects?

Brigitte Ciapa and Christophe Arnoult

Int. J. Dev. Biol. (2011) 55: 143-152

Oscillatory $\mathrm{Ca} 2+$ dynamics and cell cycle resumption at fertilization in mammals: a modelling approach Geneviève Dupont, Elke Heytens and Luc Leybaert

Int. J. Dev. Biol. (2010) 54: 655-665

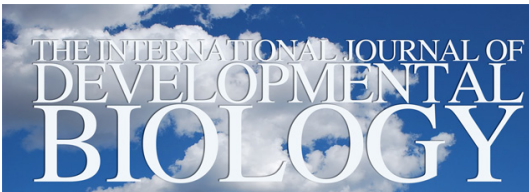

Volume 56 Nos. 10/11/12 Special Issue
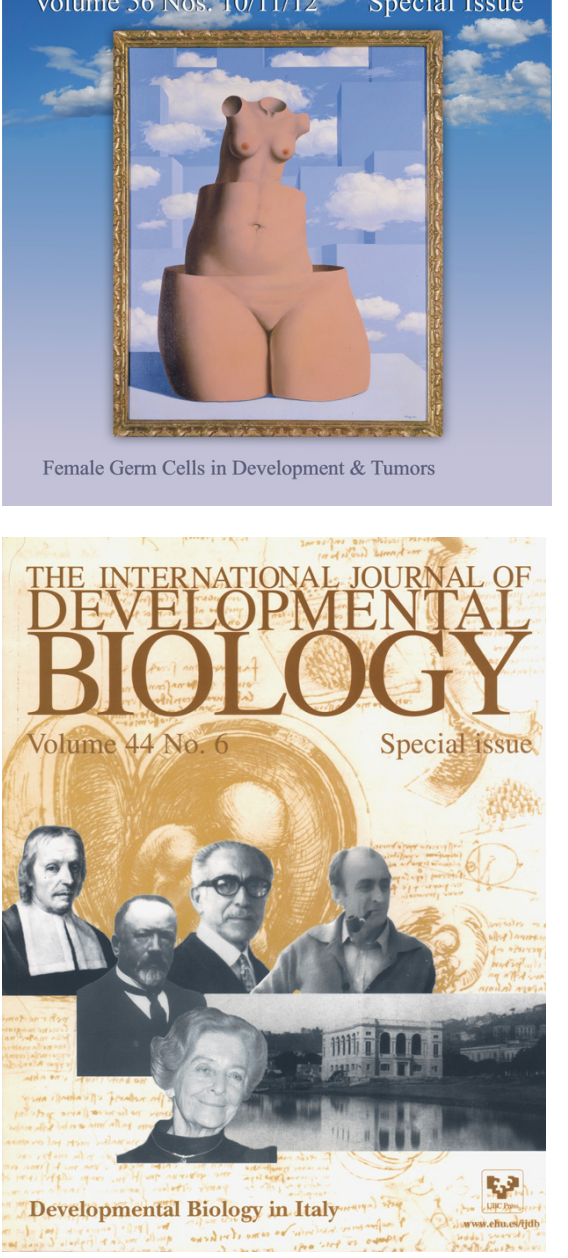

The role of ion fluxes in polarized cell growth and morphogenesis: the pollen tube as an experimental paradigm

Erwan Michard, Filipa Alves and José A. Feijó

Int. J. Dev. Biol. (2009) 53: 1609-1622

Sperm-activating peptides in the regulation of ion fluxes, signal transduction and motility

Alberto Darszon, Adán Guerrero, Blanca E. Galindo, Takuya Nishigaki and Christopher D. Wood

Int. J. Dev. Biol. (2008) 52: 595-606

The dynamics of calcium oscillations that activate mammalian eggs

Karl Swann and Yuansong Yu

Int. J. Dev. Biol. (2008) 52: 585-594

The choice between epidermal and neural fate: a matter of calcium. Marc Moreau and Catherine Leclerc Int. J. Dev. Biol. (2004) 48: 75-84
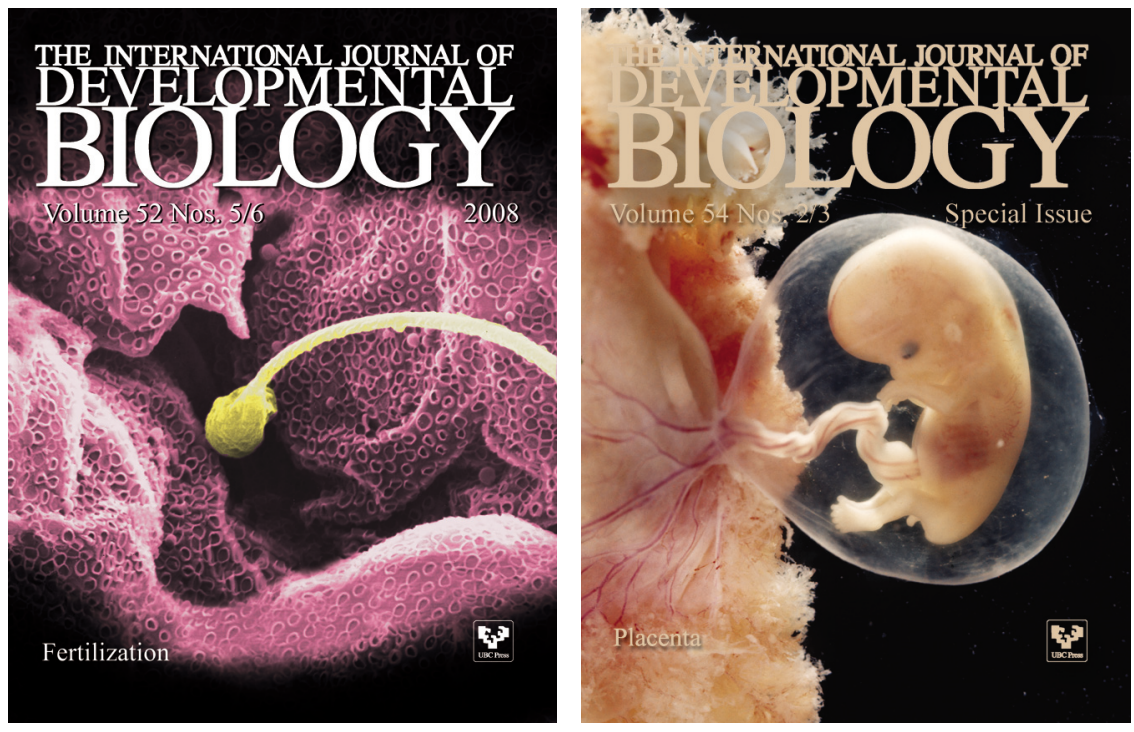